\title{
Research on Packaging Mode of Clothing Brand
}

\author{
Sheng Mao \\ Jiangxi Institute of Fashion Technology \\ Nanchang, Jiangxi, China 330201
}

\begin{abstract}
The ultimate goal of enterprise is to reflect the economic value and social value. In the process of clothing brand's growth and development, operators are trying to explore a series of strategies that can promote brand development. The brand packaged with wise strategy may occupy the reliable position in competitive market. In order to occupy the strong economic and political position, brand operators are trying to package themselves. Clothing itself is of the visual effect of packaging, and clothing brand packaging need more visual packaging. Starting from the background of the current clothing business, this paper analyzes the packaging ways for brand to expand market, and has comprehensively analyzed the development and growth of clothing brand from high quality products to the application of marketing model, from veryknown store development to focus on technological content focus, from celebrities to star charm packaging, etc.
\end{abstract}

Keywords-clothing brand; packaging way; quality; star; famous store

\section{INTRODUCTION}

Modern clothing is obviously a kind of material and spiritual packaging goods. In the modern society with highly developed spiritual civilization, spiritual packaging of clothing is more intense, which brings great challenge to a lot of clothing brands. In the era dominated by clothing material properties, quality becomes the most basic work target. And the clothing brand is measured by its quality. With the development of spiritual culture, the material properties of clothing start to transfer to the spiritual properties. The development of visual spiritual properties from germination to maturity is inseparable from the operator's efforts. Designers' packaging of the clothing design itself not only just stays on the material properties, but more on the enhancement of spiritual artistic accomplishment level. Dior designer team once made art collection tour in China and Japan, to design the clothing works with local characteristics, and at the same time, they have made the world pay attention to the local fresh cultural consciousness, to improve their visual attention.

Designers just focus on the clothing itself, while decisionmakers have a wider visual range, providing the business strategies and maintaining all aspects of the brand. The imbalance of decision-making may bring the devastating blow. So decision-makers shall seize the core essentials of brand development in-depth in an all-round, multi-level and multiangle manner in terms of clothing brand's packaging way. The writher has paid attention to the trend of clothing marketing from many aspects, having certain research foundation in terms of operation and packaging ways. Most good clothing enterprises have done a lot on packaging way: packaging by virtue of stars and celebrities can enhance the brand's popularity and help the brand settle in shopping malls or the well-known stores in a well location, and seize a certain customer base. Injection of science and technology connecting with social development to enhance technological content of clothing packaging, and the enhancement of the quality of clothing itself are the conventional packaging ways of clothing brand. Under these packing ways, many brands take the road of characteristic development, leaving profound reference and learning significance to the subsequent clothing enterprises.

\section{Quality Packaging IS the Basic Packaging WAY OF BRAND}

When it comes to the clothing quality, the most we thought the quality of apparel fabric. In fact, under the clothing industry chain of modern consumption mode, the clothing quality is not only limited on the fabric, the quality of design, plate type, sales, service and after-sale and so on are the ways of modern clothing brand to package themselves. Everything has a rule. Nothing can be accomplished without norms or standards. The clothing design, production and sale are restricted by rules, and the formulation of rules is to control the quality of clothing. In fierce competition, the quality of clothing has an effect of directly determining the success of the brand. So if the clothing enterprises want to stand stable in the market, the right choice is to work on the quality. Different operators have different quality control toward the clothing. A lot of enterprises want to produce quality clothing with little expense in the process of production. But the investment of production capital is proportional to the clothing quality. In the present transition period of clothing, the famous commodities as launched by many famous clothing brands under the pressure of capital and sales channel have preferential prices but with low-quality, which makes many brand consumers disappointed. Consumers would prefer clothing brands to adapt to the social environment. The clothing with preferential price and high quality is bound to be followed.

In the many year's development of clothing industry, the author thinks that the design quality of clothing is influenced by the international fashion trend, and the international top brand leads the trend of the world; the fabric quality is concentrated on the technological content of the fabric, which is influenced profoundly by modern science and technology, and the collision between clothing and science and technology; the author discovers that the quality of the clothing's marketing and service is improved in the current clothing market. Sales site quality, service quality, and after-sale quality 
have become the main points of clothing market quality improvement, especially the clothing sales under electronic commerce mode is an important point of the quality of aftersales service, influencing enterprises' development. Modern clothing enterprises are the enterprises with multi-dimensional development, which not only improve quality packaging, but also have many ways to package themselves. By packaging themselves, the enterprises is aiming to improve their economic and political status, as only with a firm foothold, can the wide gap be crossed to become famous enterprise and brand.

\section{Star PACKAgING UNFOLDS ClOthING BRAND}

There are a lot of men of literature and writing in ancient China. They are the representatives and bright star of their times, witnessing the alternation of dynasties and the development of history, being the spokesperson of historical development. The modern stars and celebrities come into fashion with the development of communication technology. The development of television and movie art, radio, cell phones and other communication tools enables the stars and celebrities be known by thousands of households, and expedites the rapid development of modern performing arts and also drives the development pace of clothing economy. The author has paid attention to closing marketing for many years, and finds that entering into the new millennium, the clothing brand represented by stars has become a fashionable clothing marketing model, which is related to the development of the times. The rapid development of Internet and the screen image shaped by stars meet the consumers' consumption psychology. As a product of image economy and the external appearance of consumption psychology, the clothing fits the stars' temperament, image and other aspects. Star endorsement advertising for clothing has become a trend of advertising.

There are many advantages of the clothing brand represented by stars and celebrities, and spreading information through spokesperson has become an important feature for modern clothing brand to promote themselves: on the one hand, stars' temperament can improve the clothing's image and provide positive publicity, being a positive advertising investment; on the other hand, by celebrity endorsement, the stars' and celebrities' fans can be seized, to win some longterm customers. Once again, the stars and celebrities also need entity brand to package themselves to improve their value by virtue of cooperation. Besides the endorsement fee is not low, which is a lucrative income for the stars. Overall, clothing brand represented by stars and celebrities is a win-win strategy, as stars will publicize the brand virtually in their activities. And the brand will be publicized wherever the star goes, which is a silent propaganda.

\section{FAMOUS StORE PACKAGING LEADS STEAdY DEVELOPMENT OF CLOTHING}

Modern clothing enterprises have been out of production constraints, open the competition mode of marketing environment and marketing has become a key link in the process of enterprise survival and development. In traditional marketing expansion, as the main body of marketing, entity stores are often the focus of enterprise market expansion. The famous store or brand of an enterprise may become the symbol of a city, as well as the guidance and direction of the city, which is also the important direction of business operation. The packaged famous store is not only the enterprise' sales store, but also a place for the enterprise to cultivate and select talents, and then develop the brand's flagship store, acting as the pioneer of the brand and leading the enterprise's steady development.

The stores can be selected from multi-angle, and right location shall be selected to create famous store. Nowadays, the rent of entity store is expensive, so it is very critical to choose store and select the optimal solution for comprehensive analysis. Generally clothing brand will be located at department stores, shopping centers, Pedestrian Street and other commercial space with geographical advantage and popularity. Department store itself is a large famous store, settling in department stores can grasp the long term consumers with certain purchasing power, and the reception volume is proportional to the trading volume. After part of popularity is accumulated, it is a good address selection of the famous store with advantages; shopping center is popular with a large scale, but with complex purchasing level and there is often a big gap between reception volume and trading volume, yet it has a strong publicizing strength. Modern shopping center have more and more functions, providing more sales space to the clothing brand, being the first choice for selecting a store. Entity stores are revealing more and more sales defects through one hundred years' development. With the popularity of Internet, e-commerce has developed rapidly, so the ecommerce has also become a fashion for clothing brand. As the new marketing mode, e-commerce model has opened up the connection with fashion trend and science and technology. E-commerce sales model is virtual having differences with entity sales in terms of vision and touch as well as other aspects. Under the background of current low credibility, the co-development of entity store and online store is a thought for enterprise development, as it caters to consumers' consumption psychology with convenience for consumer to select, providing more thoughtful services.

\section{TeChnical Packaging Leads the ENTERPRise to KEEP PACE WITH THE TIMES}

With the society's constant advancing with the times, science and technology is accounting a bigger and bigger proportion in the clothing, and playing more and more prominent role. The recent computer aided apparel design is the perfect collision of technology and clothing with design sketch, clothing CAD and CAM, automatic discharging, automatic hanging system and so on. The development of science and technology has greatly facilitated the development of clothing design. The clothing enterprises have various competitions, and the biggest one is the competition between selling market and clothing material. Clothing material tests the application of textile technology and technological content. Modern clothing material is widely used in scientific and technical packaging. The theme of the 21 st century is green environmental protection. The sustainable development concept of "green products" and "ecological textiles" of 
clothing material has provided people with deep thinking, and the science and technology contained in it self-evident. The application of cellulosic material, protein material, natural dyes, synthetic fiber, synthetic fiber, the latest technological achievements of natural and colorful cotton fiber and new natural cellulose fiber has added more environmental protection new ideas to clothing.

Clothing marketing field is also influenced by science and technology. The development of e-commerce is closely related to science and technology, promoting the technology innovation of online store. On the basis of the aforementioned, the 3D fashion design, 3D fitting design, 3D human body measurement design come out in succession, enabling clothing be the winner of technology in the world market. Recent research results are more admirable, and $3 \mathrm{D}$ printing and intelligent fashion design have become the new topic. The power of technology promoting clothing development is more and more strong, and the investment of intelligent clothing equipment has greatly shortened the working hours, saving labor cost and improving the production quality of clothing. Modern fashion design has become a leader in technology.

The above are all the packaging ways frequently used by modern clothing enterprises. Of course, there are many other ways for packaging and brand effect enhancement, namely, Sino-foreign joint venture packaging, overseas design packaging, export sales packaging and other new models. Different clothing brand will adopt different packaging pattern due to different operators. As long as they can a suitable packaging way, the clothing brands packaged by it can improve their market position, and have a bright prospect if they are market-based. The negative selling packaging of brand-famous low-quality and brand-famous high-price as launched by clothing enterprises in recent years is the decisionmaking mistakes of the enterprise management, bringing profound negative impact on brand, influencing subsequent development of the enterprise, which is not a good way of packaging. On the whole, clothing design has a more and more broader prospect after thousand years' development and under the packaging of years. The packaging of modern clothing is paying more attention to consumers' consumption psychology, wishes, in order to realize psychological expectation of the masses. We package clothing brand with every endeavor to increase the added value of the brand, bring positive and allround development to the enterprise and the public. The development of clothing brand brings us the harmonious development of human and the environment. The welloperated business can make our life more beautiful.

\section{REFERENCES}

[1] Peng Wenxin. Study on Suitability Domestic Clothing Brand and Spokesperson [D]. Donghua University, 2008-12-01.

[2] Zhang Yanling. Study on Influencing Power Index of Star Advertisement [D]. Sichuan University, 2006-04-08.

[3] Cai Jianmei, Mr.Joe. Leader of China's Clothing Retailing Industry: Department Store Business Type Analysis [J]. Chinese Fashion, 200703-25.

[4] Jin Weisheng. Study on Current Situation of Clothing Brand Construction in Beijing Fashion Business Circle and Countermeasures [D]. Beijing Institute of Clothing Technology, 2014-12-01
[5] Gu Xiaoqing. Discussion on Relationship between Clothing Design Art and Science and Technology [J]. Science and Technology Innovation Herald, 2012-10-21

[6] Wu Qiong. Technology Content in Clothing Design Process [D]. Tianjin Polytechnic University, 2002-01-01

[7] Liang Zhihua, Zhu Quan. Discussion on Improvement of China's Clothing Quality [J]. Journal of Textile Research, 2003-08-15 